\title{
KELEMBAGAAN PENDIDIKAN SULUK DI KABUPATEN KAMPAR (TINJAUAN FUNGSI MANAJEMEN)
}

\author{
Hairi Padhol ${ }^{(1)}$ \\ Isjoni $^{(2)}$ \\ Daeng Ayub Natuna ${ }^{(3)}$ \\ ${ }^{1)}$ Post Graduate Student of Riau University \\ ${ }^{2)}$ Lecturer of Education Management Study Programme PPs University of Riau \\ ${ }^{3}$ Lecturer of Education Management Study Programme PPs University of Riau
}

\begin{abstract}
This study was a qualitative research. The thoug collection was done with technical documentation, observation and interviews. Objective (1) To know planning in institute of suluk, (2) To know management in institute of suluk, (3) To know organization in institute of suluk, (4) To know observation in institute of suluk, (5) To know follow-up in institute of suluk. Institute education of suluk one of the informal education system. Of cours, owning separate procedures and oder in management execution it, including into management education of suluk. Suluk management below/ naqsabandi tarikat head as tarikat head executor have the following ladder : someone which have been permitted to lead suluk dubed by Mursyid while under mursyid proxy and under referred as tarikat khalifah, while head as a whole and become mursyid from entire referred as Mursyid Syaidul. Usually in mursyid lifing after executin education of suluk, diploma mursyid syaidul perform mursyid, mursyid proxy and tarikat khalifa to people who assumed competent and fulfil its condition. Each time suluk is sometimes lifted by two mursyid people, three mursyid proxy people and a number of khalifa as according to its requirement. Education decentralization give to education institute and local society to process education. Thereby can be expected reaching of productivity and quality education of it self. This matter also form independence institute education.
\end{abstract}

Key words : Institute, Education, Suluk, Management function.

ABSTRAK: Penelitian ini adalah penelitian kualitatif. Pengumpulan data dilakukan dengan tehnik dokumentasi, observasi dan wawancara. Tujuan (1) Untuk Mengetahui Perencanaan dalam kelembagaan pendidikan suluk, (2) Untuk mengetahui penyelenggaraan dalam kelembagaan pendidikan suluk, (3) Untuk mengetahui pengorganisasian dalam kelembagaan pendidikan suluk, (4) untuk mengetahui pengawasan dalam kelembagaan pendidikan suluk, (5) Untuk mengetahui keefektifitasan dan tindak lanjut dalam kelembagaan pendidikan suluk. Kelembagaan pendidikan suluk salah satu dari sistem pendidikan informal. Tentu, memiliki aturan dan tata cara tersendiri dalam pelaksanaan pegelolaan pendidikannya, termasuk kedalam manajemen pedidikan suluk. Manajemen suluk dibawah pimpinan Tarikat Naqsabandi, sebagai pelaksana pimpinan Tarikat memiliki jenjang sebagai berikut: seseorang yang telah diizinkan untuk memimpin suluk diberi gelar Mursyid sedangkan dibawahnya Wakil Mursyid dan dibawahnya disebut Khalifah Tarikat, sedangkan pimpinan secara keseluruhan dan menjadi Mursyid dari seluruh jamaah disebut Saidul Mursyid. Biasanya dalam pengangkatan mursyid setelah pelaksanaan pendidikan suluk. Saidul Mursyid mengijazahkan gelar mursyid, wakil mursyid dan khalifah tarikat kepada orang-orang yang dianggap layak dan memenuhi syarat menerimanya. Setiap kali suluk terkadang diangkat dua orang mursyid, tiga orang wakil mursyid dan sejumlah khalifah sesuai dengan kebutuhan. Manajemen merupakan suatu kajian yang banyak dibahas untuk mengubah sistem pendidikan yang sentralistik kearah desentralistik. 
Desentralisasi pendidikan memberikan kewenangan kepada lembaga pendidikan dan masyarakat setempat untuk mengolah pendidikan. Dengan demikian dapat diharapkan tercapainya kualitas dan produktivitas pendidikan itu sendiri. Hal ini juga membentuk kemandirian lembaga pendidikan.

Kata kunci: Kelembagaan, Pendidikan, Suluk, Fungsi manajemen

\section{PENDAHULUAN}

Salah satu sistem pendidikan di Indonesia yaitu pendidikan informal, telah dituliskan secara gamblang apa yang dimaksud dengan pendidikan informal adalah jalur pendidikan kekeluargaan dan lingkungan. Dengan melihat sistem pendidikan diatas, khususnya pedidikan di Indonesia maka jelaslah sulukmerupakan bagian dari kelembagaan pendidikan yang tergolong kepada pendidikan informal.

Pendidikan suluk ini diharapkan bagi seseorang yang mengikutinya dapat tertanam dalam dirinya nilai-nilai yang baik. Pelaksanaan pendidikan suluk dengan tujuan adalah: (1) Amalan suluk dapat mendekatkan diri kepada Allah SWT dengan selalu banyak melakuka zikir, baik lisan mapun hati, maka dengan demikian hati mereka selalu bersih dari sifat-sifat yang buruk, (2) Amalan suluk dapat membawa seseorang berprilaku ikhlas dalam melakukan amalan/ ibadah, (3) Amalan suluk dapat membawa seseorang selalu menepati beribadah secara berjamaah terutama dalam shalat lima waktu dan amalan-amalan lainnya, (4) Setelah seseorang memasuki pendidikan suluk hendaknya melakukan amalan-amalan sunat diluar yang wajib, (5) Sesuai dengan hakikat ajaran suluk, seseorang mengerjakan amalan mahmudah (6) Ajaran suluk dapat menghambat pengaruhpengaruh keduniaan yang menyebabkan kelalaian hati untuk mengingat Allah SWT.

Kelembagaan pendidikan suluk salah satu dari sistem pendidikan yang tergolong kedalam pendidikan informal. Tentu, memiliki aturan dan tata cara tersendiri dalam pelaksanaan pegelolaan pendidikannya, termasuk kedalam manajemen pedidikan suluk. Manajemen suluk dibawah pimpinan Tarikat Naqsabandi sebagai pelaksana pimpinan Tarikat memiliki jenjang sebagai berikut: seseorang yang telah diizinkan untuk memimpin suluk diberi gelar Mursyid sedangkan dibawahnya Wakil Mursyid dan dibawahnya disebut Khalifah Tarikat, sedangkan pimpinan secara keseluruhan dan menjadi Mursyid dari seluruh jamaah disebut Saidul Mursyid.

Biasanya dalam pengangkatan mursyid setelah pelaksanaan pendidikan suluk. Saidul Mursyid mengijazahkan gelar mursyid, wakil mursyid dan khalifah tarikat kepada orang-orang yang dianggap layak dan memenuhi syarat menerimanya. Setiap suluk terkadang diangkat dua orang mursyid, tiga orang wakil mursyid dan sejumlah khalifah sesuai dengan kebutuhan.

Kita lihat kelembagaan pendidikan suluk merupakan sebuah rangkaian kegiatan pendidikanyang belatar belakang islam dan juga kajian tentang islam tentu secara nyatanya juga memiliki atura-aturan atau prosedur (manajemen) dalam pelaksanaanya. Fenomena inilah menjadi acuan dalam penelitian ini, yang terlihat sampai saat ini kelembagaan pendidikan suluk masih tetap eksis dalam menjalankan pendidikannya sampai saat ini salah satunya di Kabupaten Kampar. Oleh sebab itu, maka penelitian ini menitik beratkan kepada tinjauan fungsi manajeman dalam kelembagaan pendidikan suluk, sebab yang menjadi pertanyaannya, kelembagaan pendidikan suluk memiliki formula khusus dalam pelaksanaan kelembagaanya itu sehingga tetap berjalan sampai saat ini.

Berdasarkan uraian pada latar belakang masalah diatas dan Fokus peneltian, maka peneliti menentukan pertanyaan dalam penelitian ini adalah:
1. Bagaimana Perencanaan dalam Kelembagaan Pendidikan Suluk di Kabupaten Kampar?
2. Bagaimana tahapan penggorganisasian dalam Kelembagaan Pendidikan Suluk di Kabupaten Kampar? 
3. Bagaimana tata cara penyelenggaraan dalam Kelembagaan Pendidikan Suluk di Kabupaten Kampar?

4. Bagaimana pelaksanaan pengawasan dalam Kelembagaan Pendidikan Suluk di kabupaten Kampar?

5. Bagaimana kefektifitasan dan tindak lanjut dalam Kelembagaan Pendidikan Suluk di kabupaten Kampar?

Merujuk kepada rumusan masalah penelitian ini bertujuan sebagai berikut: Untuk menganalisis Perencanaan, Pengorganisasian, Penyelenggaraan, Pengawasan, dan Keefektifitasan serta tindak lanjut dalam kelembagaan pendidikan suluk. Manfaat penelitian ini secara teoritis adalah dapat memperkaya khasanah keilmuan pendidikan, khususnya tentang perencanaan, pegorganisasian, penyelenggaraan, pengorganisasian, dan keefektifitasan serta tindak lanjut dalam suatu organisasi. Secara praktis hasil penelitian ini diharapkan dapat menjadikan masukan yang berharga bagi pemerintah khususnya Dinas Pendidikan dan Kebudayaan Kabupaten Kampar untuk mempertimbangkan kebijakan pembangunan pendidikan, khususnya perhatian terhadap pendidikan informal, salah satunya Kelembagaan Pendidikan Suluk.

\section{METODE PENELITIAN}

Untuk mencapai tujuan penelitian dan memperoleh jawaban atas permasalah yang menajadi pembahasan, maka penelitian ini berupa pendekatan kualitatif yang bersifat empiris yang berdasarkan data-data dari lapangan peneliti berupaya mengumpulakan berabagai bentuk data dari situs penelitan
Metode penelitian ini dimulai daripenentuan responden untuk memperoleh informasi yang dibutuhkan, selanjutnya dideskripsikan serta diverifikasi dalam laporan penelitan. Penelitian ini dilaksanakan di Kabupaten Kampar yang difokuskan di dua kecamatan yaitu Kecamatan XIII Koto Kampar dan Kecamatan Koto Kampar Hulu. Waktu pelaksanaanya dimulai dari bulan November 2016 sampai dengan Maret 2017.

Data dalam penelitian ini merupakan data primer. Peneliti menghimpun langsung data tersebut, baik secara lisan dan tulisan dari situs penelitian. Data primer tersebut berkaitan dengan fokus penelitian. Oleh sebab itu peneliti berusaha memperoleh data dalam peneltian ini dari sumber data yang terdiri dari (1) Syeikh Mursyid, Wakil Syiekh Mursyid, khalifah tarikat, jamaah suluk, dan simpatisan dalam Taikat Naqsabandi. (2) dokumen berupa profil yang berhubungan dengan lembaga pendidikan suluk. (3) kegiatan, suasana, dan lingkungan internal lembaga pendidikan suluk.

Penelitian kualitatif pada umumnya menggunakan sampel bertujuan. Dalam sampel bertujuan peneliti dengan sengaja memilih individu perorangan atau situs-situs yang bermaksud untuk mempelajari atau mengetahui fenomena sentral. Jadi situs penelitian ini adalah lembaga pendidikan suluk yang ada di kabupaten Kampar. Standar yang digunakan untuk memilih informan atau situs ini adalah apakah informan atau situs tersebut sarat dengan informasi.

Alat pengumpulan data yang sering digunakan secara umum dalam penelitian kualitatif adalah wawancara, observasi lapangan, dan telaah dokumen. Untuk lebih jelasnya data dalam penelitian ini diperoleh dengan menggunakan teknik pengumpulan data sebagai berkut: 
Tabel Subfokus, Aspek Data, Informan

\begin{tabular}{|c|c|c|c|c|}
\hline No & Sub-Fokus & Aspek & Informan & Pertanyaan \\
\hline 1 & $\begin{array}{l}\text { Perencanaan } \\
\text { Kelembagaan } \\
\text { Suluk }\end{array}$ & $\begin{array}{l}\text { - Bai'ah Sebelum Suluk } \\
\text { - Biaya } \\
\text { - Adab Sebelum Suluk } \\
\text { - Pengetahuan Sebelum } \\
\text { suluk } \\
\text { - Tempat pelaksanaan suluk }\end{array}$ & $\begin{array}{l}\text { - Syaidul Mursyid } \\
\text { - Wakil Mursyid } \\
\text { - Khalifah } \\
\text { Thariqat }\end{array}$ & \\
\hline 2 & $\begin{array}{l}\text { Pengorganisasian } \\
\text { Kelembagaan } \\
\text { Suluk }\end{array}$ & $\begin{array}{l}\text { - Struktur organisasi suluk } \\
\text { - Fungsi dan tugas dari } \\
\text { (syekh mursyid, Khalifah } \\
\text { Thariqat, jamaah, dan } \\
\text { simpatisan) }\end{array}$ & $\begin{array}{l}\text { - Syaidul Murrsyid } \\
\text { - Mursyid } \\
\text { - Khalifah Thariqat } \\
\text { - Jamaah } \\
\text { - simpatisan }\end{array}$ & \\
\hline 3 & $\begin{array}{l}\text { Penyelenggaraan } \\
\text { Kelembagaan } \\
\text { Suluk }\end{array}$ & $\begin{array}{l}\text { - Adab dalam suluk } \\
\text { - Pelaksanaan suluk } \\
\text { - Ketentuan dalam suluk } \\
\text { - Pengetahuan dalam suluk } \\
\text { - Pengetahuan diluar suluk }\end{array}$ & $\begin{array}{l}\text { - Syekh Mursyid } \\
\text { - Mursyid } \\
\text { - Khalifah thariqat } \\
\text { - Jamaah suluk }\end{array}$ & $\begin{array}{l}\text { Butir pertnyaan } \\
\text { disesuaikan } \\
\text { dengan kebutuhan } \\
\text { informasi }\end{array}$ \\
\hline 4 & $\begin{array}{l}\text { Pengawasan } \\
\text { kelembagaan Suluk }\end{array}$ & $\begin{array}{l}\text { - Adab diluar suluk } \\
\text { - Proses pengawasan dalam } \\
\text { kelembagaan pendidikan } \\
\text { suluk }\end{array}$ & $\begin{array}{l}\text { - Syekh Mursyid } \\
\text { - Mursyid } \\
\text { - Khalifah thariqat } \\
\text { - Jamaah suluk }\end{array}$ & \\
\hline 5 & $\begin{array}{l}\text { Keefektifitasan dan } \\
\text { tindak lanjut } \\
\text { Kelembagaan } \\
\text { Suluk }\end{array}$ & $\begin{array}{l}\text { - Kerukunan Intern dan } \\
\text { Ekstrn jamaah thariqat }\end{array}$ & $\begin{array}{l}\text { - Syekh Mursyid } \\
\text { - Mursyiid } \\
\text { - Khalifah Thariqat } \\
\text { - Jamaah suluk } \\
\text { - Simpatisan } \\
\text { - Masyakat umum }\end{array}$ & \\
\hline
\end{tabular}

\section{HASIL DAN PEMBAHASAN}

Suluk merupakan pekerjaan rasul-rasul dan wali-wali allah yang kita disuruh untuk mengikutinya. Nabi allah adam pada waktu khalwat di jabal Hindi dia menerima wahyu pertama, dan nabi Nuh pun berkhalwat sebelum didatangkan topan (banjir) di suati bukit tempat dia dilahirkan. Nabi Ibrahim berkhalwat di jabal Qubis dan jabal rahma, juga di tempat kuburan tidak jauh dari baitul maqdis. Nabi musa pun juga berkhalwat di bukit Tursina. Amalan suluk itu tidak terlepas dari dzikir. Yakni sesudah kita mempelajari amalan dzikir hendaklah pergi mengasingkan diri dengan mengerjakan amalan dan bacaan-bacaan dzikir. Banyak sebenarnya dalil-dalil wajib bersuluk. Tetapi qaidah ini hanya berlaku bagi orang yang mendapat petunjuk kepada jalan kebenaran.

Pelaksanaan pendidikan suluk tidak terlepas dari aturan suluk itu sendiri. pekerjaan suluk itu ada beberapa perkara. Antara lain, menjauhi pergaulan dengan makhluq, meninggalkan pekerjaan dunia, memerangi hawa nafsu, bersungguh-sungguh pada amalan dzikir dan sembahyang sunnah serta menggunakan semua waktu dengan wirid-wirid dan dzikir-dzikir siang dan malam. Adapaun beberapa pasal terkandung dalam suluk berdasarkan dokumen dari ajaranajaran suluk Thariqat Naqsabandi yaitu:

\section{Adab Suluk}

Berdasarkan sabda Nabi Saw yang artinya : Barang siapa tidak beradab, maka tidak ada ilmu baginya walaupun berilmu. Adapaun adab suluk ada tiga yaitu :

(a). Adab Sebulum Suluk.

Adapaun adab sebelum suluk ada enam yaitu:

1. Hendak memilih guru yang mursyid pemimpin suluk.

2. Selesaikan pekerjaan dunia yang 
membimbangkan di dalam hati waktu suluk.

3. Hendaklah meninggalkan nafkah bagi orang yang wajib di nafkahi.

4. Meniatkan diri pergi mati, maka minta maaflah kepada kerabat dan tetanggatetangga.

5. Hendaklah diakuinya dirinya banyak dosa dan banyak kekurangan.

6. Apabila sudah bertemu dengan guru mursyidnya hendaklah mandi taubat sebagaimana disuruh gurunya kemudian menyerahkan diri seberapa waktu yang ditentukan.

(b) Adab Dalam Suluk

Adab dalam suluk ada 21 yaitu:

1. Hendaklah ia berniat ikhlas semata-mata mengerjakan ibadah dan mengerjakan semua perintah mursyidnya semata-mata untuk mencari keridoan Allah.

2. Meninggalkan keinginan tercela seperti ingin dipuji orang, atau ingin jadi kulafak (khalifah) dan lain-lainnya.

3. Senantiasa hormat dan beradab kepada mursyid-robithanya yang memimpin suluk.

4. Hendaklah meniatkan diri seakan-akan berada dalam kurungan yang tidak boleh lepas karena sangat garang dan buas.

5. Menjaga dawam wudhu. Jika batal cepatlah berwudhu lagi.

6. Jangan ketinggalan sembahyang berjamaan satu kali pun.

7. Mengasingkan diri.

8. Bekal yang dibawa bersuluk harus halal dan suci.

9. Sedang masak harus suci dari hadast besar dan hadast kecil.

10. Menyedikitkan minum jangan terlalu banyak minum

11. Menyedikitkan makan jangan terlalu kenyang.

12. Jangan memakan jenis yang bernyawa.

13. Menyedikitkan tidur.

14. Tidur miring kekanan dan menyelonjorkan kaki seperti mayit dalam kuburan.
15. Menyedikitkan bicara. Berkata yang perluperlu saja.

16. Membersihkan hati untuk menghadap allah.

17. Apabila keluar dari tempatnya hendaklah menundukkan kepala sampai dengkluk.

18. Jangan ketinggalan bertwajuhan bahkan harus lebih dahulu duduk dari gurunya dan kemudian bangkit setelah gurunya bangkit.

19. Hendaklah jujur kepada mursyidnya dan meminta izin setiap apa-apa hendak yang dilakukan kecuali kejamban dan berwudu.

20. Hendaklah melaporkan tentang apa-apa yang didapatkan dalam dzikir- dan murokobah dan menyimpannya.

21. Hendaklah beradp pula kepada khulapak yang menjaga hal ahwal didalam suluk serta bayak-banyak sedekah didalam suluknya.

(c) Adab Sesudah Bersuluk

Adab sesudah bersuluk ada Sembilan yaitu:

1. Hendaklah kuat-kuat dan banyak-banyak dzikir dan muroqobah supaya menetap nikmat-nikmat yang didapat didalam suluk.

2. Hendaklah berjamaah awajuhan pada malam jumat dan malam selasa.

3. Hendaklah memilihara nikmat-nikmat yang didapat didalam suluk lebih daripada simpinan emas dan perak karena ini adah setengah dari rahasia ma'rifah.

4. Hendaklah banyak-banyak berbuat yang bermanfaat untuk umum, khususnya keapda orang islam.

5. Jangan bersahabat dengan orang yang anti kepada pekerjaan suluk karena orang yang anti kepada pekerjaan suluk itu hilang iman dan islamnya karena pekerjaan suluk itu pekerjaan nabi saw dan para ambiya yang dahulu-dahulu dan pekerjaan wali-wali allah.

6. Hendaklah saling bertolong-tolong dalam pekerjaan suluk.

7. Hendaklah selalu bergaul dengan gurunya jikalau memungkinkan, jikalau tidak, maka hendaklah senantiasa memberikan hatinya kepad gurunya.

8. Hendaklah lebih baik atau waro' daripada sebelum suluk. 
9. Hendaklah diitiqadnya gurunya, khalifah Rasulullah saw selalu menerima nasihat daripadanya.

Berdasarkan hasil observasi pelaksanaan pendidikan suluk umumnya di kabupaten Kampar dan khsususnya di Kecamatan XIII Koto Kampar dan Koto Kampar Hulu dapat di kategorikan kedalam 2 waktu :

\section{Menjelang Hari Raya Idul Fitri.}

Pada waktu ini, pendidikan suluk dilakukan selama 40 hari atau sering sisebut suluk 40 hari. Waktunya ini dimulai dari tanggal 20 sya'ban dan berakhir pada tanggal 30 Ramadhan, pendidikan suluk ini ditutup dengan masuknya hari raya Idul Ftiri. Setelah solat hari raya Idul fitri, para jamaah atau peserta pendidikan suluk diperbolehkan pulang dan berkumpul bersama keluarganya.

\section{Menjelang Hari Raya Idul Adha.}

Pada waktu ini, pendidikan suluk hanya dilakukan 20 hari atau disebut juga dengan suluk 20 hari. Kegiatan ini dimulai dari tanggal 20 Zulkaidah sampai 10 Zulhijjah, yaitu berakhir setelah melaksanakan solat hari raya idul adha.

Dengan melihat fungsi manajemen secara umum untuk melakukan suatu rangkaian kegiatan dalam sebuah organisasi atau lembaga memang menerapkan fungsi-fungsi manajemen. Kita lihat kelembagaan suluk merupakan sebuah rangkaian kegiatan pendidikan yang berlatar belakang islam dan juga kajian tentang islam tentu secara nyatanya juga memiliki aturan-aturan atau prosedur (manajemen) dalam pelaksanaannya yang dijalankan sangat efektif cuma perbedaan mendasar adalah tidak ditulis secara administrasi namun pelaksanannya sangat efektif sesuai dengan tuntutan fungsi-fungsi manajemen.

\section{SIMPULAN DAN SARAN}

Perencanaan dalam kelembagan Pendidikan suluk, sebelum seseorang memasuki pendidikan yang harus diketahui oleh jamaah pendidikan suluk itu adalah Rukun suluk sebagaimana yaitu:

(a) Berniat masuk suluk dengan ikhlas, (b) Dengan suruhan Mursyid/Khalifah diyakini dengan ikhlas, (c) Mengambil khalwat seperti didalam kubur, (d) Tiga kali bertawajjuh dan berkhatam sehari semalam. Kemudian juga harus diketahui adab-adab dalam pendidikan suluk, seperti adab sebelum suluk ada 6 , adab dalam suluk ada 21, dan adab sesudah suluk ada 9. Hal ini berguna bagi jamaah suluk untuk keberlangsungan dan keberkahan dalam amalan yang dikerjakan.

Pengorganisasian dalam kelembagaan pendidikan suluk, memiliki struktur oragnisasi tersendiri yaitu peranan seorang syekh mursyid tetap menjadi kedudukan yang teratas dalam kehidupan keagamaan para jamaah dan simpatisannya. Tingkatan-tingkatan dalam struktur organisasi tersebut juga memiliki peran serta tugas masing-masing dan pengetahuan sesuai dengan tingkatan yang telah diraih oleh jamaah pendidikan suluk setelah mengikuti pendidikan suluk tersebut.

Penyelenggaraan dalam kelembagaan pendidikan suluk, juga tidak terlepas dari adab dan ketentuan dari aturan thariqat naqsabandi itu sendiri baik itu seperti pelajaran-pelajaran yang dipelajari dalam masa pendidikan, pantang dan larang saat dalam proses pendidikan suluk serta, amalan yang harus dilakukan di luar pendidikan suluk.

Pengawasan dalam kelembagaan pendidikan suluk, juga memiliki perbedaan dengan organisasi-orgnisasi keagamaan atau kelembagaan lainnya. Perbedaan itu adalah pengawasan secara tidak tertulis tapi melalui ikatan-ikatan perjanjian (bai,ah) yang berdasarkan kepada pengawasan batiniah.

Keefektifitasan dan tindak lanjut dalam kelembagan pendidikan suluk yang dilakukan oleh jamaah thariqat naqsabandi atau jamaah pendidikan suluk melalui kegiatan intern dari dalam jamaah thariqat tersebut juga melalui kegiatan ekstern yaitu diluar kegiatan jamaah thariqat naqsabandi yang berhubungan langsung kepada masyarakat luas berdasarkan adab-adab dalam pengetahuan thariqat naqsabandi tersebut. Tapi, yang perlu digaris bawahi adalah efektifnya kelembagaan pendidikan suluk sampai saat ini 
adalah kepatuhan jamaah terhadap adab-adab dalam peraturan pendidikan suluk dan hubungan robitoh yang dijadikan sebagai pengikat sesama antar jamaah tariqat naqsabandi mulai dari syekh mursyid, khalifah, jamaah suluk, dan simpatisan.

Thariqat merupakan salah satu metode tobat, sedangkan suluk merupakan jalan memperdalam tobat tersebut.

Berdasarkan kesimpulan maka saran yang diberikan dan diajukan dalam penelitain ini adalah:

1. Perencanaan dalam kelembagaan pendidikan suluk perlu ditingkatkan sosialisasinya kepada jamaah calon pendidikan suluk, sehingga dalam pelaksanaannya berjalan lancar dan lebih khsusuk.

2. Penyelenggaraan dan pengorganisasian dalam kelembagaan pendidikan suluk memberikan contoh pendidikan yang berkarakter yang harus di contoh oleh kita semua, hal ini berhubungan dengan tingkat kepercayaan terhadap pemimpin menghilangkan sikap krisis keyakinan terhadap pemimpin yang menyebabkan terjadinya perpecah belahan.

3. Pengawasan dan keefektifitasan serta tindak lanjut dalam kelembagaan pendidikan juga harus menjadi perhatian kita bersama karena mereka memberikan contoh perbuatan yang baik sesama manusia, sehingga memunculkan rasa persatuan dan kesatuan kita dalam beragama, bermasyarakat, dan bernegara.

4. Diharapkan kepada semua jamaah thariqat naqsabandi untuk dapat membuka diri, sehingga ilmu-ilmu yang dipelajari dalam pendidikan suluk sedikit dapat terbuka, sehingga mudah dicontoh kepada masyarakat umumnya.

5. Kepada insan yang berkecimpung di dunia pendidikan khususnya pihak pengambilan keputusan, hendaknya mencontoh metode pendidikan yang diterapkan dalam kelembagaan pendidikan suluk, sehingga bisa menopang unsur-unsur negatif dalam norma kehidupan masyarakat pada saat ini, untuk pendidikan kita yang lebih baik dan berkarakter.

\section{DAFTAR PUSTAKA}

Abu Bakar Aceh. 1966. Pengantar Ilmu Tarikat. Jakarta: Towi dan Sog Bok

Ahmad Mustafa Al-Maraghi. 1974. Tafsir AlMaraghi, Maktabati Wamath-baati Mustthafal Babil Halbi Mesir.

Aprijon Efendi. 2013. Biografi Syeikh Abdul Ghani El-Khalidi, Pekanbaru: Zanafa Publising.

Ayi Karyana 2013. Pengaruh iklim organisasi terhadap produktifitas kerja di unit pelaksana teknis kurikulum kecamatan jasingan kabupaten bogor. Jurnal organisasi dan manajemen vol.8(1):67-68.

Daryanto. 2013. Administrasi dan Manajemen Sekolah, Jakarta : Rineka Cipta.

Emzir. 2012. Metodologi Penelitian Pendidikan : Kuantitatif \& Kualitatif, Jakarta : PT Raja Grafindo Persada.

Engkoswara. 2012. Administrasi Pendidikan, Jakarta: Alfabeta

George Zaidan. Tanpa Tahun. Al-Munjid Fillughati Wal- A'lam, Darul Masriq Bairut.

H. A. Fuad Said. 1983. Syekh Abdul Wahab Tuan Guru Babussalam, Medan : Pustaka Babussalam.

Hamid Patilima. 2011. Metode Penelitian Kualitatif, Jakarta: Alfabeta.

Hasri Salfen. 2005. Manajemen Pendidikan : Pendekatan Nilai dan Budaya Organisi, Makasar: Yapma

Idris Taher. 1986. Skripsi : Kehidupan beragama Jamaah Tarikat Naqsabandi di Kecamtan XIII Koto Kampar.

Mahmud Yunus. 1973. Kamus Arab Indonesia, Yayasan Penyelenggaraan Penterjemahan Penafsiran Al-Qur'An Jakarta.

Margono, S. 2010. Metodologi Penelitian Pendidikan, Jakarta : Rineka Cipta.

M. Manullang. 2006. Dasar-dasar Manajemen, Yogjakarta: Gajah Mada University Press. 
Muhammad bin Ahmad, Abdurrahman bin Abu Bakar, Asysyayuthi. Tanpa Tahun. Tafsir Al-jalalain, Bandung.

Mulyasa E. 2003. Kurikulum Berbasis Kompetensi:konsep, karakteristik, dan implementasi, Bnadung : PT Rosda Karya.

Mustafa Zahri. 1984. Kunci Memahami Ilmu Tasawwuf. Surabaya: PT ilmu.

Nanang Fattah. 2009. Landasan Manajemen Pendidikan, Bandung: Adira.

Samiaji Sarosa. 2012. Penelitian Kualitatif : dasar-dasar. Jakarta: PT Indeks.

Sugiyono. 2010. Metode Kualitatif dan R \& $D$, Bandung: Alfabeta. 2013. Metode Penelitian Manajemen, Bandung: Alfabeta.
Suranto dan Etty Puji Lestari.2015.Pengaruh motivasi, gaya kepemimpinan, dan disiplin kerja terhadap kinerja pegaai KKPN percontohan jambi, bangko, dan muaro bungo. Jurnal organisasi dan manajemen. Vol 10(2):148-160

Winarno Surachman. 1980. Metodologi Riset, Penelitian, Jakarta: Galia Indonesia Hidayah Press.

Husaini Usman. Tanpa Tahun. Manajemen (Toeri, Praktik, dan Riset Pendidikan), Bumi Aksara Jakarta.

Miftah Toha. 2012. Organisasi: Konsep Dasar dan Aplikasinya. Jakarta : Raja Grapindo Persada.

UU. RI No. 20 Tahun 2003 Tentang Sistem Pendidikan Nasional. 